\title{
The medical treatment of the actinic keratosis and the skin tumours: photodynamic therapy (PDT)
}

\author{
E Provenzano ${ }^{*}$, S Spadafora \\ From de Senectute: Age and Health Forum \\ Catanzaro, Italy. 5-7 December 2009
}

Though the experimental studies on the activation of "photodynamic" medications was only published 1999, the FDA approved the use of the ALA (Aminolevulinic) in the dermatologic field.

In substance, the PDT by using photosensitive medicines at a topical level (ALA and MAL), a luminous source with an appropriate wavelength for their activation, set the formation of protoporphyrin IX and when it returns to its native state, reacts with molecular oxygen and forms reactive species like the "singoletto" oxygen.

The formation of this substance is to the base of the fall events that may lead to the destruction of the cellule through the:

- apoptosis, the damage of the mitochondrial and cell membranes

- damage of the endothelium from the oxygen radicals

- inflammatory process

- induction of the immune answer

The PDT is a valid alternative to chirurgic treatment for the basocellular epitelioma and actinic keratosis when subsist particular health conditions of the patient or when the number and the centre of the wounds make the chirurgic act hard to be applied.

After personal experiences have been reported, we will speak of the advantages and disadvantages of the method and for which patients this cure is recommended.

Published: 19 May 2010

Unit of Dermatology, Cosenza Hospital, Italy
doi:10.1186/1471-2318-10-S1-L44

Cite this article as: Provenzano and Spadafora: The medical treatment of the actinic keratosis and the skin tumours: photodynamic therapy (PDT). BMC Geriatrics 2010 10(Suppl 1):L44.
Submit your next manuscript to BioMed Central and take full advantage of:

- Convenient online submission

- Thorough peer review

- No space constraints or color figure charges

- Immediate publication on acceptance

- Inclusion in PubMed, CAS, Scopus and Google Scholar

- Research which is freely available for redistribution

Submit your manuscript at www biomedcentral.com/submit
C Biomed Central 